\title{
BMJ Global Heath Pandemic treaty needs to start with rethinking the paradigm of global health security
}

\author{
Sakiko Fukuda-Parr (D) , ${ }^{1}$ Paulo Buss, ${ }^{2}$ Alicia Ely Yamin ${ }^{3}$
}

To cite: Fukuda-Parr $\mathrm{S}$, Buss $\mathrm{P}$, Ely Yamin A. Pandemic treaty needs to start with rethinking the paradigm of global health security. BMJ Global Health 2021;6:e006392. doi:10.1136/ bmjgh-2021-006392

Received 24 May 2021 Accepted 25 May 2021

Check for updates

(C) Author(s) (or their employer(s)) 2021. Re-use permitted under CC BY-NC. No commercial re-use. See rights and permissions. Published by BMJ.

'International Affairs, The New School, New York, New York, USA

${ }^{2}$ Centro de Relações Internacionais em Saúde, Fundacao Oswaldo Cruz, Rio de Janeiro, Brazil

${ }^{3}$ Petrie-Flom Center for Health Law Policy, Biotechnology and Bioethics, Harvard Law School, Cambridge, Massachusetts, USA

Correspondence to

Professor Sakiko Fukuda-Parr; fukudaps@newschool.edu
The Independent Panel on Pandemic Preparedness ${ }^{1}$ released on 11 May adds to the mounting calls for a new Pandemic Treaty that would address gaps in the global governance of threats to global health security. The emerging debate has quickly turned to focus on questions of structure and forms-a United Nations treaty or a framework convention under the auspices of the WHO, and verification and enforcement mechanismsas well as on issues of process regarding who will have voice and how the negotiations will proceed. ${ }^{23}$ But we must not lose sight of its purpose and key objectives, and what we mean by 'global health security'. Indeed, the treaty discussions provide an opportunity and an imperative to rethink the paradigm of global health security that has shaped the current international response to the COVID-19 pandemic. The prevailing paradigm is antithetical to the core purpose of global pandemic preparedness and response for five reasons.

First, global health security needs to focus on the security of people, not national borders. The concept of 'global health security' emerged with the increasing transnational spread of disease in the late 20th century in the context of neoliberal economic globalisation, the rise in biosecurity threats, and increased migrations due to climate change, instability and armed conflicts. ${ }^{45}$ It led to a reframing of infectious diseases as a national security threat, bringing the language and thinking of the security sector, concerned with defending national borders, not human health. As Senators Obama and Lugar wrote in a New York Times editorial 'Grounding a Pandemic' on 6 June 2005 to urge policy attention to prepare for a pandemic, 'When we think of the major threats to our national security, the first to come to mind are nuclear proliferation, rogue states and global terrorism. But another kind of threat lurks beyond our shores, one from nature, not humans'. ${ }^{6}$ A framing of global health security that focuses on the security of a country bounded by borders is antithetical to the aim of the treaty as expressed by the original call from 25 political leaders issued on 30 March $2021^{7}$ that emphasised 'health for all' and the health security of individuals, that is, health security as part of human security. ${ }^{8}$

Second, global health security calls for multilateral action, not go-it-alone national policies. The Panel report as well as the original call from political leaders emphasised interdependence as the rationale for multilateral action. The rapid spread of variants shows the folly, as well as immorality, of putting national interest above concerted global action. In national defence strategies, mutual interest of states is recognised but does not come first as it must in public health emergencies. The truism that "nobody is safe until everyone is safe' means focusing on the provision of global public goods that would serve the needs of all people, universallysuch as the 'people's vaccine'.

Third, institutional arrangements for global health security need to be based on fundamental human rights principles as well as the specific legally binding norms in treaties countries have already ratified. Universal access to healthcare, the essential role of public health infrastructures and ensuring substantive equality for diverse human beings' needs are core principles that underpin human rights in relation to health. Such concerns tend to be obscured in security thinking that privileges technological surveillance tools. However, it is not enough to paste human rights language onto a pandemic treaty or 'mainstream' human rights in the work of international agencies without addressing the structural inequalities between countries embedded in the architecture of governance for global health. 
Fourth, the prevailing paradigm of global health security needs to be decolonised. It is built around an implicit assumption that pandemics emanate from poorer regions of the world, threatening the health and wellbeing of people in the more prosperous areas. ${ }^{9}$ As Senators Obama and Lugar continued in their 2005 op ed,

in an age when you can board planes in Bangkok or Hong Kong and arrive in Chicago, Indianapolis or New York in hours, we must face the reality that these exotic killer diseases are not isolated health problems half a world away, but direct and immediate threats to security and prosperity here at home. (Italics ours) ${ }^{5}$

Thus, the centrepiece of global health security regimes, notably the International Health Regulations (IHR), is to create a high-performing system for surveillance of outbreaks of new pathogens that could protect the public health and economic interests (especially through trade) of the Global North from the diseases presumed to rage uncontrolled in the Global South. Although there is language about international cooperation to support the local public health capacity needed in low-income and middle-income countries necessary for controlling infectious diseases, the binding public health obligations in the IHR focus on sharing information and materials.

We have yet to see how a proposed pandemic treaty is meant to relate to the IHR, which were largely sidelined during COVID-19. But current debates about a proposed pandemic treaty largely focus on enforceability in relation to the willingness of governments of the Global South to share information and materials with the WHO and other governments, and to allow independent verification.

Fifth, the geography of COVID-19 should make us question the criteria and institutions that might assess pandemic preparedness. Until the surge of cases in India starting in early 2020, global incidence and deaths from COVID-19 have been overwhelmingly concentrated in North America and Western Europe. Many commentators have observed the irony of the Johns Hopkins Index of Global Security—a 'gold standard' ranking system that resulted from a massive effort drawing on top expertisethat placed the US first and the UK second, whereas many countries considered to be poorly prepared-such as Bhutan or Laos-have had very few COVID-19 deaths. ${ }^{10}$

The current challenges of vaccine equity for COVID-19 make these five challenges amply clear. Although R\&D has been largely publicly financed, pharmaceutical monopolies have been allowed to retain intellectual property rights. The resulting artificial scarcity and 'vaccine nationalism' were as predictable as they have proven lethal. Lack of global inoculation will prolong the pandemic, retard economic recovery and inflict incalculable unnecessary harm on both health and livelihoods around the globe.

The prevailing global health security paradigm does nothing to challenge the devastating effects of neoliberal legality and the unfettered power of private actors to control the infrastructure of health provision, including pharmaceutical companies. The most important thing a pandemic treaty could do to create genuine global health security focused on human security is to mandate sharing of technologies and know-how in future pandemics.

Twitter Sakiko Fukuda-Parr @sfparr and Alicia Ely Yamin @AE_Yamin

Contributors Each and every one of the three contributing authors participated in drafting the manuscript and will participate in review and revision.

Funding The authors have not declared a specific grant for this research from any funding agency in the public, commercial or not-for-profit sectors.

Competing interests None declared.

Patient consent for publication Not required.

Provenance and peer review Not commissioned; internally peer reviewed.

Data availability statement There are no data in this work.

Open access This is an open access article distributed in accordance with the Creative Commons Attribution Non Commercial (CC BY-NC 4.0) license, which permits others to distribute, remix, adapt, build upon this work non-commercially, and license their derivative works on different terms, provided the original work is properly cited, appropriate credit is given, any changes made indicated, and the use is non-commercial. See: http://creativecommons.org/licenses/by-nc/4.0/.

\section{ORCID iD}

Sakiko Fukuda-Parr http://orcid.org/0000-0002-6004-3606

\section{REFERENCES}

1 Make it the Last Pandemic. Independent panel on pandemic preparedness, 2021. Available: https://theindependentpanel.org/ mainreport/

2 Mahjour at G2H2 panel on the pandemic Treaty proposal. Geneva. Available: https://g2h2.org/posts/may2021/

3 Nikogosian $\mathrm{H}$, Kickbusch I. The case for an international pandemic Treaty. BMJ 2021;372:n527.

4 Brundtland GH. Global health and international security, global governance: a review of Multilateralism and international organizations, 2003: 417-23.

5 Lo Yuk-ping C, Thomas N. How is health a security issue? Politics, responses and issues. Health Policy Plan 2010;25:447-53.

6 Obama B, Lugar R. Grounding a pandemic, 2005. New York Times. Available: https://www.nytimes.com/2005/06/06/opinion/groundinga-pandemic.html

7 Bainimarama JV, Chan-o-cha P, Costa ALS. COVID-19 shows why United action is needed for more robust international health architecture. WHO, 2021. Available: https://www.who.int/newsroom/commentaries/detail/op-ed-covid-19-shows-why-unitedaction-is-needed-for-more-robust-international-health-architecture

8 Sen A. 'Birth of a discourse'. In: Martin M, Owen T, eds. Routledge handbook of human security. London/NY: Routledge, 2013.

9 Cash R, Patel V. Has COVID-19 subverted global health? Lancet 2020;395:1687-8.

10 Mahajan M. Casualties of preparedness: the global health security index and COVID-19. International Journal of Law in Context 2021;17:204-14. 